\title{
THE SECTORAL EMPLOYMENT EFFECTS OF INTERNATIONAL TRADE AND PRODUCTIVITY IN THE MANUFACTURING INDUSTRY OF TURKEY
}

DOI: 10.17261/Pressacademia.2021.1447

JBEF- V.10-ISS.3-2021(4)-p.138-147

\section{Guzin Emel Akkus}

Istanbul University, Faculty of Economics, Department of Economics, Istanbul, Turkey. eakkus@istanbul.edu.tr, ORCID: 0000-0002-0200-4123

\begin{tabular}{l} 
Date Received: June 18, $2021 \quad$ Date Accepted: September 24, 2021 \\
\hline To cite this document \\
Akkus, G.E., (2021). The sectoral employment effects of international trade and productivity in the manufacturing industry of Turkey. Journal \\
of Business, Economics and Finance (JBEF), 10(3), 138-147. \\
Permanent link to this document: http://doi.org/10.17261/Pressacademia.2021.1447 \\
Copyright: Published by PressAcademia and limited licensed re-use rights only. \\
\hline
\end{tabular}

\section{ABSTRACT}

Purpose-Turkish international trade mainly consists of the sectors of manufacturing industry and also determines the dynamics in this industry. Therefore, export demand, import competition and technological changes (productivity) are very important topics for the sectors of Turkish manufacturing industry. Besides the direct employment effects of international trade, trade variables influence productivity and therefore indirectly affect employment. This study empirically analyzes the direct and indirect effects of international trade on sectoral employment in the Turkish manufacturing industry.

Methodology-The data used in this study includes 22 sectors of the Turkish manufacturing industry for the period of $2009-2017$. The panel data techniques are employed. Industry classification is NACE Rev. 2 (2-digit).

Findings-The estimations show that international trade is effective on sectoral employment in the Turkish manufacturing industry. Both export demand and import penetration have a significant impact on sectoral employment in Turkey. While the increase in export demand leads to an increase in labour demand, the increase in import penetration reduces it. However, the relationship between productivity and international trade makes a negative effect on sectoral employment. The strong negative relationship between import competition and productivity, measured by value added per worker, suggests that firms, when faced with international competition, can not adjust the level of employment to decreased demand. On the other hand, the main determinant of productivity in the Turkish manufacturing industry seems to be investment expenditures.

Conclusion- According to our findings, international trade is an important determinant of sectoral employment in the Turkish manufacturing industry. There is a positive relationship between export demand and employment while the relationship is negative for import competition. However, export demand is not a significant factor for productivity while import competition and productivity is negatively related. On the other hand, the main determinant of productivity in the Turkish manufacturing industry is investment expenditures. The productivity equation shows that this variable is positive and statistically significant.

Keywords: International Trade, Export Demand, Import Competition, Productivity, Employment.

JEL Codes: F14, F16, L60

\section{INTRODUCTION}

Turkey experienced a major structural change in the 1980s by shifting from an import substituting industrialization strategy to an export-oriented growth model via implementing an orthodox structural adjustment program. Turkey has also gone through a substantial process of liberalization at the national as well as international level in the 2000 s and it is seen as a successsful example of integration to the world economy.

Turkish international trade mainly consists of the sectors of manufacturing industry and also determines the dynamics in this industry. Therefore, export demand, import competition and technological changes (productivity) are very important topics for the sectors of the Turkish manufacturing industry. Turkish export flows consist mainly of manufactures. And foreign demand is a crucial determinant of the demand for manufacturing output.

This study empirically analyzes the effects of international trade and productivity on employment in the Turkish manufacturing industry. It investigates the employment effects of trade within the framework of the Heckscher - Ohlin Samuelson (HOS) theory. There is a positive relationship between an expansion in export demand and the demand for labour. On the other hand, imports have adverse effects on sectoral employment. In addition to the direct employment effects of trade, trade variables influence productivity and therefore indirectly affect employment. This relationship leads to the productivity effect of international trade on employment. 
According to the reasoning behind this relationship: (i) exports and / or import competition affect technology (measured by productivity) and (ii) this increase in productivity affects employment. The effect of international trade on productivity can work in both directions. On the one hand, domestic firms that can not cope with foreign competition are faced with falling productivity. Large hiring and firing costs which are present in the European economies may prevent domestic companies facing decline in sales from internal restructuring in the form of lay-offs. On the other hand, international trade can increase productivity if it can induce firms to successfully introduce productivity-enhancing technologies (Abraham and Brock, 2003: 224).

The second section of the study is a survey of the literature on the relationship between trade, productivity and employment. The third section explains the data and methodology used in this study and the fourth section explains the empirical results on the relationship between trade and sectoral employment, trade and productivity and finally productivity and sectoral employment in the manufacturing industry of Turkey. The last section includes concluding remarks. Some descriptive statistics regarding the Turkish manufacturing industry and import shares by industries are given in the Appendix.

\section{LITERATURE REVIEW}

Revenga (1992) investigates the effect of increased import competition on employment and wages in the U.S. manufacturing industry using panel data method over the 1977-1987 period. Revenga finds that changes in import prices have a statistically significant but small effect on sectoral employment.

Revenga (1995) studies the employment and wage effects of trade liberalization on the Mexican manufacturing industry using a panel data set of firms for the $1984-90$ period. Mexico initiated a radical liberalization of its external sector in 1985, after decades of an import-substitution industrial strategy.

The paper finds that reductions in quota coverage and in tariff levels lead to only small reductions in firm-level employment. According to the empirical results, a 10 point decrease in tariff levels, such as that experienced by Mexico between 1985 and 1990 , is associated with a $2-3 \%$ reduction in employment.

Neven and Wyplosz (1999) focus also on the import competition effect on labour markets for German, French, Italian and UK manufacturing industries for the period 1976-90. Neven and Wyplosz can not find a strong support for the Heckscher-OhlinSamuelson effect of import competition on employment. But they do observe a substantial and diverse restructuring in unskilled labour intensive industries.

Larre (1995) investigates the possible relationships between foreign trade, employment and relative wages using data for 21 industries in 12 OECD countries, over the period 1970-89. The findings of this time-series analysis indicate that the impact of trade on labour market conditions seems to be significant but generally small relative to other factors and the most significant relationships are observed in the high-skill industries.

Dutt, Mitra and Ranjan (2009) present a model of trade and unemployment for 92 countries over the period 1985-2004 for panel analysis, where trade results from Heckscher-Ohlin comparative advantage based on international differences in relative factor endowments and/or Ricardian comparative advantage based on relative technological differences.

The results of cross-sectional analysis, which present fairly strong and robust evidence for the Ricardian prediction show that unemployment and trade openness are negatively related. This effect dominates the positive Heckscher-Ohlin effect of trade openness on unemployment for capital abundant countries, which turns negative for labour-abundant countries. The results of panel data analysis show that trade liberalization increases unemployment in the short-run, but reduces in the long-run.

Castro, Olarreaga ve Saslavsky (2007) attempt to estimate the effects of trade with China and India on Argentina's industrial employment between 1991 and 2003 during which industrial employment declined by 31 percent. They use a dynamic econometric model and industry level data to estimate the effects of trade with China and India on the level of employment in Argentina's manufacturing sector.

The empirical results suggest that import competition from China and India only had a small negative effect on industrial employment, even during the fast trade liberalization of the 1990s. On the other hand, exports do not seem to contribute to the employment in the manufacturing industry of Argentina.

Bernard and Jensen (1999) analyze the interaction between exporting and firm performance for the USA over the 1984-1992 period. They ask two key questions:

"do good firms become exporters and do exporters outperform non-exporters" (Bernard and Jensen, 1999: 2).

The answer for the first question is clear but they can not find any positive evidence for the second question (Bernard and Jensen, 1999: 23-24) :

...we conclude that there is substantial evidence that success and new products lead to exporting, and that exporting is associated with growth in plant size. However, the lack of productivity gains suggest that firms entering the export market are unlikely to substantially raise their productivity, even if they export continuously. 
Bernard and Jensen (2001) also examines the relationship between productivity and exporting in the U.S. manufacturing sector for the 1983-1992 period. They can not find again any evidence for a positive impact of exports on productivity:

...Building on previous research, we have found no evidence that exporting per se is associated with faster productivity growth rates at individual plants. The positive correlation between exporting and productivity levels appears to come from the fact that high productivity plants are more likely to enter foreign markets (Bernard and Jensen, 2001: 17).

Then, “...causality goes in the other direction: more productive firms become better exporters" (Abraham and Brock, 2003: 225).

Abraham and Brock (2003) estimate the direct and productivity related indirect effects of international trade on sectoral employment in 10 industralized European countries for the period of 1978-1994.

They have found significant effects from both international trade directly and productivity indirectly towards sectoral employment in Europe. They find support "...for the hypothesis that international trade induces adjustments in technology".

Lawrence (2000), explores the effect of international competition on technological change empirically for the USA during the period 1978-89. Technological change is measured by changes in total factor productivity and the skill ratio in U.S. manufacturing.

In this study, the empirical results confirm that import competition has a positive effect on US total factor productivity. The results of Lawrence also show the importance of differentiating between imports from developed and developing countries. In particular, total factor productivity growth is relatively faster in industries with a relatively large share of imports from developing countries.

...Since such industries also employ relatively higher shares of workers with a high school education or less, this implies that international competition has led to relatively faster productivity growth in unskilled-labour intensive sectors (Lawrence, 2000: 216).

The studies analyzing the relationship between trade and employment in Turkey are mostly focused on the direct affect of trade or trade liberalization (globalization) on employment.

Gül And Kamacı (2012), examines the effects of international trade on employment using a panel data analysis for developed and developing countries (including Turkey) in the periods of 1980-2010 and 1993-2010, respectively. As a result of their empirical tests, it has been concluded that there is not any influences of unemployment on import and export in both developed and developing countries. On the other hand, they have found a causality relationship from import and export to unemployment in both developed and developing countries.

Erlat (2000) investigates the impact of export and import flows on the change in employment of the manufacturing industry of Turkey. The analysis covers the periods before 1980 when Turkey switched from a regime of import-substitution based growth to one of export-orientation and after 1980. In this study, manufacturing industry is categorized as net exporting, import competing and noncompeting sectors. The results show that the impact of trade on employment change is more significant in the post-1980 periods and that this is observed more in the net exporting and noncompeting categories rather than the import competing category. The expansion in exports after 1980 has contributed to the increase in employment of Turkish manufacturing industry.

Ayaş and Çeştepe (2010) study the effects of foreign trade on employment in the Turkish manufacturing industry for the period of 1998-2002. These effects are examined according to input-output and factor intensity models by using 1998 and 2002 input-output tables. Their calculations reveal that the effects of foreign trade on employment change from sector to sector; while trade increases employment in some sectors, it reduces in some other sectors. But the total effect of foreign trade on employment in the Turkish manufacturing industry is positive.

According to the empirical results, the sectors with the highest employment increase, such as chemicals, chemical products, rubber and plastic products and basic metal sectors, have also the highest increase in import. This result shows that the employment effect in the manufacturing industry is based on the increases in import. Therefore, this study supports the idea that production and employment in the Turkish manufacturing industry depend substantially on imported inputs.

There are few studies analyzing the effect of trade on both employment and productivity in the manufacturing industry of Turkey.

Turco and Maggioni (2013) investigates the impact of trade on the firm employment level and composition by providing evidence for the Turkish manufacturing industry over the period 2003-2008. Authors evaluate Turkey as an interesting case within this framework as it has undergone a continuous and growing integration process in the global economy since 1980 s. According to their empirical evidence, productivity gains are associated with the internationalisation of Turkish firms. They also study the effect of the firm trade integration strategies on its employment composition in terms of the ratio of R\&D to non R\&D workers.

The empirical findings show that entering the export and the import markets at the same time gives the highest employment growth in the entry and the following years by the existence of complementarity effects between the two strategies. The 
investigation of the trade intensity reveals that although labour demand is positively affected, regardless of the firm degree of involvement in foreign markets, firms entering both export and import markets with a high intensity experience higher employment growth. Finally, the share of R\&D employees increases only by high intensity exporting and such trade activity is the driver of innovation.

Their results do not support decreases in employment due to existing international integration process. On the contrary, the firm trade activity positively affects the evolution of manufacturing employment within the stagnant Turkish labour market. More importantly, they show that entry in both the import and the export markets, relevantly increases the firm scale of operations. Therefore, internationalisation provides firms with higher growth prospects and represents a significant channel for employment creation.

In conclusion, the evidence of this paper on Turkey suggests that policy makers in emerging economies should be concerned about enhancing the firm involvement in foreign markets, as it represents a powerful tool to foster firm growth (Turco and Maggioni, 2013: 18).

On the other hand, Meschi, Taymaz and Vivarelli $(2008,2011)$ analyses the relationship between trade openness, technology adoption and relative demand for skilled labour in the Turkish manufacturing industry using firm-level data over the period 1980-2001. They estimate the impact of trade openness on labour demand by using a unique database of 17,462 firms. This data set covers all manufacturing firms employing 10 or more people and represents about $90 \%$ of manufacturing output.

The analysis reveals that in Turkey the relative demand for skills increased substantially over the 1980-2001 period, when Turkey underwent radical policy changes favouring trade liberalisation. According to empirical results, the mutual influence between trade openness and technology adoption was the central factor in shifting the demand for labour towards more skilled workers within each firm. Technology related variables (domestic R\&D expenditures and technological transfer from abroad) are positively and significantly related to skill upgrading.

The sectoral analysis shows that increasing export towards more industrialised countries (mainly the E.U.) tends to shift the production toward less skill-intensive activities. This result is consistent with the Heckscher-Ohlin's theorem and in its StolperSamuelson corollary (HOSS theorem); on the other hand, import penetration from more developed countries promotes the adoption of new technologies embodied in capital and intermediate goods. Therefore, it switchs the production for more skill-intensive technologies.

Besides, firms belonging to those sectors that most raised their imported inputs from more developed countries also increased their demand for skilled workers. The idea behind this finding is that imports by a middle income country from industrialised countries imply a transfer of new technologies that are more skill-intensive than those previously in use in domestic markets and lead to a higher demand for skilled labour.

The papers on Turkey show that international trade usually affects employment in a positive manner in the manufacturing industry. On the other hand, international trade stimulates innovation and firms may engage in innovative efforts and endow themselves with skilled workforce. The mutual influence between trade openness and technology adoption is the key factor in shifting the demand for labour towards more skilled workers within each firm.

\section{DATA AND METHODOLOGY}

The current study analyzes the effects of international trade and productivity on the sectoral employment in the manufacturing industry of Turkey. For this purpose, two regression equations are estimated.

Employment Equation:

$E M P_{i t}=\alpha_{i 1}+\beta_{1}\left(E P_{i t}\right)+\chi_{1}\left(I M P_{i t}\right)+\eta_{1}\left(W A G E_{i t}\right)+\lambda_{1}\left(P R O D_{i t}\right)+u_{1 i t}$

Productivity Equation:

$P R O D_{i t}=\alpha_{i 2}+\beta_{2}\left(E X P_{i t}\right)+\chi_{2}\left(I M P_{i t}\right)+\phi_{2}\left(I N V_{i t}\right)+\delta_{2}\left(R D_{i t}\right)+u_{2 i t}$

While in the first equation, the effects of international trade (export and import) and productivity on sectoral employment are investigated, the second equation estimates the effects of international trade on productivity. This equation also includes investment and research-development expenditures, which show the impact of technological innovations on productivity.

In this model, employment (or labour demand) is explained by export demand, import penetration, wage per person employed and productivity that is measured by value added per person employed (Equation 1). Employment equation estimates the direct impact of export demand $\left(\beta_{1}\right)$ and import competition $\left(\chi_{1}\right)$ on the sectoral employment in Turkish Manufacturing industry. This regression equation also estimates the effect of productivity $\left(\lambda_{1}\right)$ on employment which is one aspect of the productivity effect of international trade on employment.

On the other hand, productivity is explained by export demand, import penetration, investment expenditures per person employed and research\&development expenditures per person employed (Equation 2). The important point here is the impact of trade integration on productivity which is the other aspect of the productivity effect of international trade on employment. The other variables in the productivity equation are for measuring the effect of the changes in investment 
expenditures that affects capital stock finally, and of research and development expenditures on productivity. Whether companies adopt labour-saving or labour-augmenting technologies as a result of international trade is important for the sign of productivity parameter in the employment equation. If $\lambda_{1}$ parameter is positive, increases in productivity are labouraugmenting; when $\lambda_{1}$ is negative, increases in productivity are labour-saving.

The data used in this study is described as below:

$\mathrm{EMP}=$ Number of persons employed in the sectors of the manufacturing industry (i and $t$ refer respectively to industry and time).

EXP $=$ Sectoral exports which shows the export demand effect.

IMP = Import penetration ratio which is defined as imports divided by the difference between sectoral production and sectoral net exports:

(Import / Production - Net Exports)

Import competition is measured by import penetration.

WAGE $=$ Wages - Salaries and social security payments per person employed in the manufacturing industry .

PROD = Labour productivity which is measured by value added at factor cost per person employed in the related sector of the manufacturing industry.

INV = Fixed capital investment expenditures per person employed in the manufacturing industry.

RD = Research and Development Expenditures per person employed in the manufacturing industry.

Data Source: Turkish Statistical Institute (TUIK) Databases for Annual Industry And Service Statistics and Foreign Trade Statistics. All variables are expressed in dollars and all variables except import penetration ratio are shown in logarithms. Data set covers 22 sectors in the Turkish manufacturing industry.

Classification: "Statistical Classification of Economic Activities in the European Community" (NACE), Revision 2 (2-digit).

Time Period: 2009-2017. Due to the difficulties of finding regular data for all sectors, the study was constrained to include the period 2009-2017.

Some descriptive statistics for the 22 sectors of the Turkish Manufacturing Industry and import shares for these sectors are given in the Appendix.

\section{EMPIRICAL RESULTS}

The employment and productivity equations (Equation 1 and 2) are estimated by using panel data econometrics. The empirical analysis of the 22 sectors of the Turkish manufacturing industry during 2009 to 2017 constitutes 198 observations. Two stage least squares approach is used in order to capture in the employment equation only the productivity changes that are explained by export demand, import penetration and other productivity variables. The fitted values of the productivity variable obtained by the estimation of Equation 2 are substituted into Equation 1.

\subsection{Trade and Employment}

The estimation results for Equation 1 are presented in Table 1. The regression coefficients for export demand $\left(\beta_{1}\right)$, import penetration $\left(\chi_{1}\right)$ and productivity $\left(\lambda_{1}\right)$ are $0.47,-0.33$ and -1.31 respectively. While the export demand affects employment positively, import competition makes a negative effect on it.

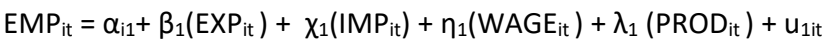

The productivity variable in the employment equation is obtained from the second equation. After productivity equation is estimated, employment equation (Equation 1) is estimated where the productivity variable is instrumented by using the fitted values from the productivity regression.

The impact of productivity on employment is one aspect of the productivity effect of international trade on employment. However, productivity variable, which is measured by value added per person employed in this study, makes a statistically significant negative effect on sectoral employment in the Turkish manufacturing industry. 
Table 1: The Regression Results of the Employment Equation

Dependent Variable: EMP

Method: Random - effects GLS regression

Sample: 2009-2017

Period included: 9

Cross-sections included: 22

Total panel (balanced) observations: 198

Overall R - Squared: 0.7903

\begin{tabular}{|c|c|c|c|c|}
\hline Variable & Coefficient & $\begin{array}{c}\text { Drisc. / Kraay } \\
\text { Std. Error }\end{array}$ & t- Value & p - Value \\
\hline Constant & $14.648^{* * *}$ & 3.134 & 4.67 & 0.002 \\
\hline EXP & $0.473^{* * *}$ & 0.079 & 5.98 & 0.000 \\
\hline IMP & $-0.334^{* * *}$ & 0.043 & -7.73 & 0.000 \\
\hline WAGE & 0.005 & 0.003 & 1.51 & 0.169 \\
\hline PROD & $-1.314^{* * *}$ & 0.126 & -10.43 & 0.000 \\
\hline
\end{tabular}

Note : ${ }^{* * *}$ Significance at $1 \%$ percent.

\subsection{Trade And Productivity}

The estimation results for Equation 2 are presented in Table 2. While the impact of productivity on employment is one aspect of the productivity effect of international trade on employment, the other aspect of this effect concerns the effect of trade integration on productivity.

$P R O D_{i t}=\alpha_{i 2}+\beta_{2}\left(E X P_{i t}\right)+\chi_{2}\left(I M P_{i t}\right)+\phi_{2}\left(I N V_{i t}\right)+\delta_{2}\left(R D_{i t}\right)+u_{2 i t}$

Export demand is not a statistically significant source of productivity in the manufacturing industry of Turkey. The increases in export demand do not make a positive contribution to labour productivity (value added per person employed) in Turkish manufacturing industry.

The negative coefficient before import competition variable suggests that increased import competition causes a loss in productivity in the Turkey's manufacturing industry. This supports the view that restructuring is a difficult process in Turkey as well as in Europe. "Companies going through rising foreign competition that reduces their sales are unable to scale down their factor use at the same rate" (Abraham and Brock, 2003: 229).

However, it is not found a statistically significant relationship between export demand and productivity. These findings support the estimations of the productivity equation. According to Bernard and Jensen $(1999,2001)$, the causality between these two variables work in the other direction: "more productive firms become better exporters but there is no evidence that exporting increases the productivity growth rates of firms."

Investment expenditures per worker have positive impact on the productivity of the Turkish manufacturing industry. In the light of these estimations, it is possible to conclude that the main contributors of productivity in the manufacturing industry of Turkey are new investments realized in the related sectors.

\section{Table 2: The Regression Results of the Productivity Equation}

\begin{tabular}{|c|c|c|c|c|}
\hline \multicolumn{5}{|c|}{$\begin{array}{l}\text { Dependent Variable: PROD } \\
\text { Method: Fixed - effects regression } \\
\text { Sample: } 2009-2017 \\
\text { Period included: } 9 \\
\text { Cross-sections included: } 22 \\
\text { Total panel (balanced) observations: } 198 \\
\text { Within R - Squared: } 0.0590\end{array}$} \\
\hline Variable & Coefficient & $\begin{array}{c}\text { Drisc. / Kraay } \\
\text { Std. Error }\end{array}$ & t- Value & $p$ - Value \\
\hline Constant & 8.393 & 1.548 & 5.42 & 0.001 \\
\hline EXP & -0.002 & 0.034 & -0.06 & 0.956 \\
\hline IMP & $-0.103^{* *}$ & 0.036 & -2.85 & 0.021 \\
\hline INV & $0.140 * *$ & 0.055 & 2.54 & 0.034 \\
\hline RD & 0.011 & 0.027 & 0.40 & 0.700 \\
\hline
\end{tabular}

Note : ** Significance at $5 \%$ percent. 


\subsection{Prroductlvlty Related And Total Effects of Internatlonal Trade on Employment}

Combining two aspects of this model produces the productivity effects of international trade on employment. When we substitute productivity equation into employment equation.

$E M P_{i t}=\alpha_{i}+\beta\left(E P_{i t}\right)+\chi\left(I M P_{i t}\right)+\eta\left(W A G E_{i t}\right)+\phi\left(I N V_{i t}\right)+\delta\left(R D_{i t}\right)+u_{i t}$

$\alpha_{i}=\alpha_{i 1}+\lambda_{1} \alpha_{i 2} ; \quad \beta=\beta_{1}+\lambda_{1} \beta_{2} ; \chi=\chi_{1}+\lambda_{1} \chi_{2} ; \eta=\eta_{1} ; \phi=\lambda_{1} \phi_{2} ; \delta=\lambda_{1} \delta_{2} ; u_{i t}=u_{1 i t}+u_{2 i t}$.

The estimation results for Equation 3 are presented in Table 3.

Table 3: The Regression Results of the Employment Equation

\begin{tabular}{|c|c|c|c|c|}
\hline \multicolumn{5}{|c|}{$\begin{array}{l}\text { Dependent Variable: EMP } \\
\text { Method: Fixed - effects regression } \\
\text { Sample: } 2009-2017 \\
\text { Period included: } 9 \\
\text { Cross-sections included: } 22 \\
\text { Total panel (balanced) observations: } 198 \text {; Within R - Squared : } 0.6118\end{array}$} \\
\hline Variable & Coefficient & $\begin{array}{c}\text { Drisc. / Kraay } \\
\text { Std. Error }\end{array}$ & t- Value & p - Value \\
\hline Constant & 4.630 & 3.611 & 1.28 & 0.236 \\
\hline EXP & $0.488 * * *$ & 0.113 & 4.31 & 0.003 \\
\hline IMP & $-0.182^{*}$ & 0.087 & -2.09 & 0.070 \\
\hline WAGE & 0.006 & 0.004 & 1.39 & 0.201 \\
\hline INV & $-0.292^{* *}$ & 0.125 & -2.34 & 0.048 \\
\hline RD & 0.004 & 0.024 & 0.15 & 0.886 \\
\hline
\end{tabular}

Note : ${ }^{* * *}$ Significance at $1 \%$ percent ; $^{* *}$ Significance at $5 \%$ percent; ${ }^{*}$ Significance at $10 \%$ percent.

In the Tables 4 and 5 below, direct and productivity related employment effects of export demand and import competition are calculated by the aid of the parameter coefficients produced by employment and productivity equations.

Total Impact of export demand: $\beta=\beta_{1}+\lambda_{1} \beta_{2}$

The total impact of export demand on employment is measured by the $\beta$ coefficient which is the sum of the direct effect of export demand on employment $\left(\beta_{1}\right)$ and the effect of an increase in export demand on employment that occurs via an increase in productivity $\left(\lambda_{1} \beta_{2}\right)$.

Table 4 gives the direct and indirect effects of export demand on employment. Since there is not a significant relationship between export demand and productivity ( $\beta_{2}$ parameter) in Turkish manufacturing industry according to our estimations, productivity related effects of exports on employment are ignorable $\left(\lambda_{1} \beta_{2}\right.$ parameter).

Actually, total effect in the table below is mainly the result of the direct effect of export demand on employment, which is positive and statistically significant ( $\beta_{1}$ parameter).

Total Impact of import competition: $\chi=\chi_{1}+\lambda_{1} \chi_{2}$

Similarly, $\chi$ refers to the total impact of import competition on employment and consists of the direct $\left(\chi_{1}\right)$ and the productivity induced effects $\left(\lambda_{1} \chi_{2}\right)$ of import competition on sectoral employment.

Table 5 gives the direct and indirect effects of import competition on employment. The productivity related effect of import penetration on employment is statistically significant and negative $\left(\lambda_{1} \chi_{2}\right.$ parameter).

Increasing import competition results in decreasing jobs in the manufacturing industry of Turkey when we take into consideration the direct employment and productivity effects of import competition ( $\chi_{1}$ and $\chi_{2}$ parameters).

Table 4: The Productivity Related and Total Effects of Export Demand on Employment

\begin{tabular}{|c|c|c|}
\hline \multicolumn{3}{|c|}{$\boldsymbol{\beta}=\boldsymbol{\beta}_{\mathbf{1}}+\boldsymbol{\lambda}_{\mathbf{1}} \boldsymbol{\beta}_{\mathbf{2}}$} \\
\hline Export Demand Effect $\left(\boldsymbol{\beta}_{\mathbf{1}}\right)$ & Productivity Related Effect $\left(\boldsymbol{\lambda}_{\mathbf{1}} \boldsymbol{\beta}_{\mathbf{2}}\right)$ & Total Effect $(\boldsymbol{\beta})$ \\
\hline 0.473 & 0.003 & 0.476 \\
\hline
\end{tabular}

Note: Created using Tables 3 and 4.

Table 5: The Productivity Related and Total Effects of Import Competition on Employment

\begin{tabular}{|c|c|c|}
\hline \multicolumn{3}{|c|}{$\chi=\chi_{1}+\lambda_{1} \chi_{2}$} \\
\hline Import Competition Effect $\left(\chi_{1}\right)$ & Productivity Related Effect $\left(\boldsymbol{\lambda}_{1} \chi_{2}\right)$ & Total Effect $(\boldsymbol{\chi})$ \\
\hline-0.334 & 0.135 & -0.199 \\
\hline
\end{tabular}

Note: Created using Tables 3 and 4. 
The coefficient values displaying the total effects of export and import calculated by using the estimated coefficients of Equation 1 and 2 are in harmony with those estimated by Equation 3.

The calculated coefficient for export in Table 4 is 0.476 whereas the estimated value for it in Table 3 is 0.488 . The calculated coefficient for import is -0.199 in Table 5 but the estimated value for it in Table 3 is -0.182 . The results are rather close.

\section{CONCLUSION}

This paper investigates the sectoral employment effects of international trade and productivity in the manufacturing industry of Turkey. There are several important conclusions of this study.

First of all, international trade is effective on sectoral employment in the Turkish manufacturing industry. Both export demand and import penetration have a significant impact on sectoral employment in Turkey. While the increase in export demand leads to an increase in labour demand, the increase in import penetration reduces it.

Secondly, the relationship between productivity and international trade makes a negative effect to sectoral employment. Export demand is not a statistically significant source of productivity in the manufacturing industry of Turkey. The increases in export demand do not make a positive contribution to labour productivity (measured by value added per person employed) in the Turkish manufacturing industry. International trade can increase productivity if it can induce firms to successfully introduce productivity-enhancing technologies. According to Bernard and Jensen (1999, 2001), the causality between these two variables work in the other direction: "more productive firms become better exporters but there is no evidence that exporting increases the productivity growth rates of firms."

Therefore, total effect of export demand on employment in the manufacturing industry of Turkey is mainly the result of the direct effect of it, which is positive and statistically significant. Since there is not a significant relationship between export demand and productivity in the manufacturing industry according to our estimations, productivity related (indirect) effects of exports on employment are ignorable.

The strong negative relationship between import competition and productivity suggests that increased import competition causes a loss in productivity in the Turkey's manufacturing industry. This supports the view that restructuring is a difficult process in Turkey as well as in Europe. "Companies going through rising foreign competition that reduces their sales are unable to scale down their factor use at the same rate" (Abraham and Brock, 2003: 229). More clearly, the domestic firms that can not cope with foreign competition are faced with falling productivity. Large hiring and firing costs which are present in the Turkish economy as well as in European economies may prevent domestic companies facing decline in sales from internal restructuring in the form of lay-offs.

As a result, the overall impact of import competition on employment results from both direct and productivity-related (indirect) effects of import competition on sectoral employment in the Turkish manufacturing industry. Increasing import competition results in decreasing jobs in the manufacturing industry of Turkey when we take into consideration the direct employment and productivity effects of import competition. Because the productivity related effect of import penetration on employment is statistically significant and negative.

Third, the main determinant of productivity in Turkish manufacturing industry is investment expenditures. The productivity equation shows that this variable is positive and statistically significant.

\section{REFERENCES}

Abraham F., Brock, E. (2003). Sectoral employment effects of trade and productivity in Europe. Applied Economics. 35(2), 223-238. Retrieved from https://doi.org/10.1080/00036840210161828

Ayaş, N., Çeştepe, H. (2010). Dış ticaretin istihdam üzerindeki etkileri: türk imalat sanayi örneği. Süleyman Demirel Üniversitesi İktisadi ve İari Bilimler Fakültesi Dergisi. 15(2), 259-281. Retrieved from https://dergipark.org.tr/tr/pub/sduiibfd/issue/20827/223030

Baltagi, B. H. (1995). Econometric Analysis of Panel Data. Chichester, John Wiley\&Sons.

Bernard, A. B., Jensen, J. B. (1999). Exceptional exporter performance: cause, effect or both? Journal of International Economics. 47 (1), 125. Retrieved from https://doi.org/10.1016/S0022-1996(98)00027-0

Bernard, A. B., Jensen, J. B. (2001). Exporting and Productivity: The Importance of Reallocation. NBER Working Paper Series, 7135, 1-31. Retrieved from http://www.nber.org/papers/w7135.pdf

Castro, L., Olarreaga, M. And Saslavsky, D. (2007). The Impact of Trade with China and India on Argentina's Manufacturing Employment. World Bank Policy Research Working Paper. 4153, 1-30. Retrieved from https://econpapers.repec.org/RePEc:wbk:wbrwps:4153

Dutt, P., Mitra D., Ranjan P. (2009). International trade and unemployment: theory and cross - national evidence. Journal of International Economics. 78(1), 32-44. Retrieved from http://www.sciencedirect.com/science/article/pii/S0022-1996(09)00022-1

Erlat, G. (2000). Measuring the ımpact of trade flows on employment in the Turkish manufacturing Industry. Applied Economics. 32(9), 11691180. Retrieved from http://www.tandfonline.com/doi/abs/10.1080/000368400404317

Greene, W.H. (2003). Econometric Analysis. New Jersey, Prentice Hall. 
Gül, E., Kamacı, A. (2012). Effects of International trade on employment: a panel data analysis. Anadolu University Journal of Social Sciences, 12 (4), 23-32. Retrieved from https://dergipark.org.tr/tr/download/journal-file/20339

Hadri, K. (2000). Testing for stationarity in heterogeneous panel data. Econometrics Journal, 3(2), 148-161. Retrieved from https://EconPapers.repec.org/RePEc:ect:emjrnl:v:3:y:2000:i:2:p:148-161

Hill, R.C., Griffiths, W. H., Lim, G. C. (2011). Principles of Econometrics. Fourth Edition. John Wiley \& Sons.

Im, K.S., Pesaran, M.H., Shin, Y. (2003). Testing for unit roots in heterogeneous panels. Journal of Econometrics, 115 (1), 53-74. Retrieved from http://www.sciencedirect.com/science/article/pii/S0304-4076(03)00092-7

Larre, B (1995). The Impact of Trade on Labour Markets: An Analysis By Industry. OECD Jobs Study Working Papers, 6, 1-35. Retrieved from https://doi.org/10.1787/247442101034

Lawrence, R.Z. (2000). Does a kick in the pants get you going or does it just hurt? The impact of international competition on technological change in US manufacturing. (In) The Impact of International Trade on Wages. (Ed.) Feenstra, R. C. University of Chicago Press, 197-224.

Levin, A.T., Lin, C.F., Chu, C. J. (2002). Unit root tests in panel data: Asymptotic and finite- sample properties. Journal of Econometrics, 108 (1), 1-24. Retrieved from http://www.sciencedirect.com/science/article/pii/S0304-4076(01)00098-7

Meschi, E., Taymaz E., Vivarelli, M. (2008). Trade openness and the demand for skills: evidence from Turkish microdata. IZA Discussion Paper. 3887, 1-29. Retrieved from http://ftp.iza.org/dp3887.pdf

Meschi, E., Taymaz, E., Vivarelli, M. (2011). Trade, techonology and skills: evidence from Turkish microdata. Labour Economics, 18 (S1), S60S70.Retrieved from https://doi.org/10.1016/j.labeco.2011.07.001

Neven, D., Wyplosz, C. (1996). Relative prices, trade and restructuring in European industry. CEPR Discussion Papers, 1451, 1-22. Retrieved from http://www.cepr.org/active/publications/discussion papers/dp.php?dpno=1451

Revenga, A., (1992). Exporting jobs? The impact of import competition on employment and wages in US manufacturing. Quarterly Journal of Economics, 107 (1), 255-84. Retrieved from https://doi.org/10.2307/2118329

Revenga, A. (1995). Employment and Wage Effects of Trade Liberalization: The Case of Mexican Manufacturing. World Bank Policy Research Working Paper. 1524, 1-36. Retrieved from http://www-wds.worldbank.org/external/default/WDSC d/PDF/multiopage.pdf

Tatoğlu, F.Y. (2018). Panel Veri Ekonometrisi. İstanbul, Beta yayınları.

Tatoğlu, F.Y. (2018). i̇leri Panel Veri Analizi. İstanbul, Beta yayınları.

Tatoğlu, F.Y. (2018). Panel Zaman Serileri Analizi. İstanbul, Beta yayınları.

Turco, A. L., Daniela, M. (2013). Does trade foster employment growth in emerging markets? evidence from Turkey. World Development. 52 (C) 1-18. Retrieved from http://www.sciencedirect.com/science/article/pii/S0305750X13001496

Turkish Statistical Institute. Statistics and Databases. www.turkstat.gov.tr

Wooldridge J. M. (2002). Econometric Analysis of Cross Section and Panel Data. Cambridge, MIT Press.

Appendix 1: Descriptive Statistics For Turkish Manufacturing Industry (2009-2017)

\begin{tabular}{|c|c|c|c|c|c|c|c|c|c|}
\hline $\begin{array}{l}\text { Sectors } \\
\text { In Manufacturing } \\
\text { Industry } \\
\text { (NACE Rev.2) }\end{array}$ & $\begin{array}{c}\text { Employment } \\
\text { (Number of } \\
\text { Persons) }\end{array}$ & $\begin{array}{l}\text { Exports } \\
\text { (Million } \\
\text { Dollars) }\end{array}$ & $\begin{array}{l}\text { Imports } \\
\text { (Million } \\
\text { Dollars) }\end{array}$ & $\begin{array}{l}\text { Net Exports } \\
\text { (Million } \\
\text { Dollars) }\end{array}$ & $\begin{array}{c}\text { Import } \\
\text { Penetration } \\
\text { Ratio }\end{array}$ & $\begin{array}{l}\text { Personnel } \\
\text { Cost Per } \\
\text { Employee } \\
\text { (Dollar) }\end{array}$ & $\begin{array}{c}\text { Productivity - } \\
\text { Value Added Per } \\
\text { Employee } \\
\text { (Dollar) }\end{array}$ & $\begin{array}{c}\text { Investment } \\
\text { Expenditures } \\
\text { Per Employee } \\
\text { (Thousand } \\
\text { Dollars) } \\
\end{array}$ & $\begin{array}{c}\text { Research and } \\
\text { Development } \\
\text { Expenditures } \\
\text { Per Employee } \\
\text { (Dollar) } \\
\end{array}$ \\
\hline Food (10) & 432012 & 10299 & 4944 & 5354 & 8.92 & 11040 & 21210 & 111 & 119 \\
\hline Beverages (11) & 14753 & 230 & 325 & -94 & 0 & 0 & 56267 & 3237 & 74 \\
\hline Textiles (13) & 401120 & 10585 & 5210 & 5375 & 18.03 & 9252 & 19075 & 120 & 109 \\
\hline Wearing Apparel (14) & 500448 & 14413 & 2674 & 11739 & 21.47 & 7276 & 10381 & 96 & 18 \\
\hline Leather (15) & 66268 & 964 & 1398 & -435 & 31.60 & 7193 & 11466 & 721 & 23 \\
\hline $\begin{array}{l}\text { Wood, Wood } \\
\text { Products and Cork } \\
(16)\end{array}$ & 81162 & 710 & 1206 & -497 & 0 & 6453 & 15611 & 586 & 19 \\
\hline $\begin{array}{l}\text { Paper and Paper } \\
\text { Products (17) }\end{array}$ & 58027 & 1693 & 3501 & -1808 & 31.14 & 14395 & 32720 & 836 & 72 \\
\hline $\begin{array}{l}\text { Printing and } \\
\text { Reproduction of } \\
\text { Recorded Media (18) }\end{array}$ & 54972 & 19 & 46 & -27 & 1.16 & 9222 & 15839 & 863 & 49 \\
\hline $\begin{array}{l}\text { Coke and Refined } \\
\text { Petroleum Products } \\
(19)\end{array}$ & 8054 & 4920 & 14652 & -9732 & 53.78 & 40776 & 159578 & 5891 & 1337 \\
\hline $\begin{array}{l}\text { Chemicals and } \\
\text { Chemical Products } \\
(20)\end{array}$ & 75761 & 6135 & 25894 & -19759 & 65.51 & 18408 & 55592 & 629 & 1490 \\
\hline
\end{tabular}




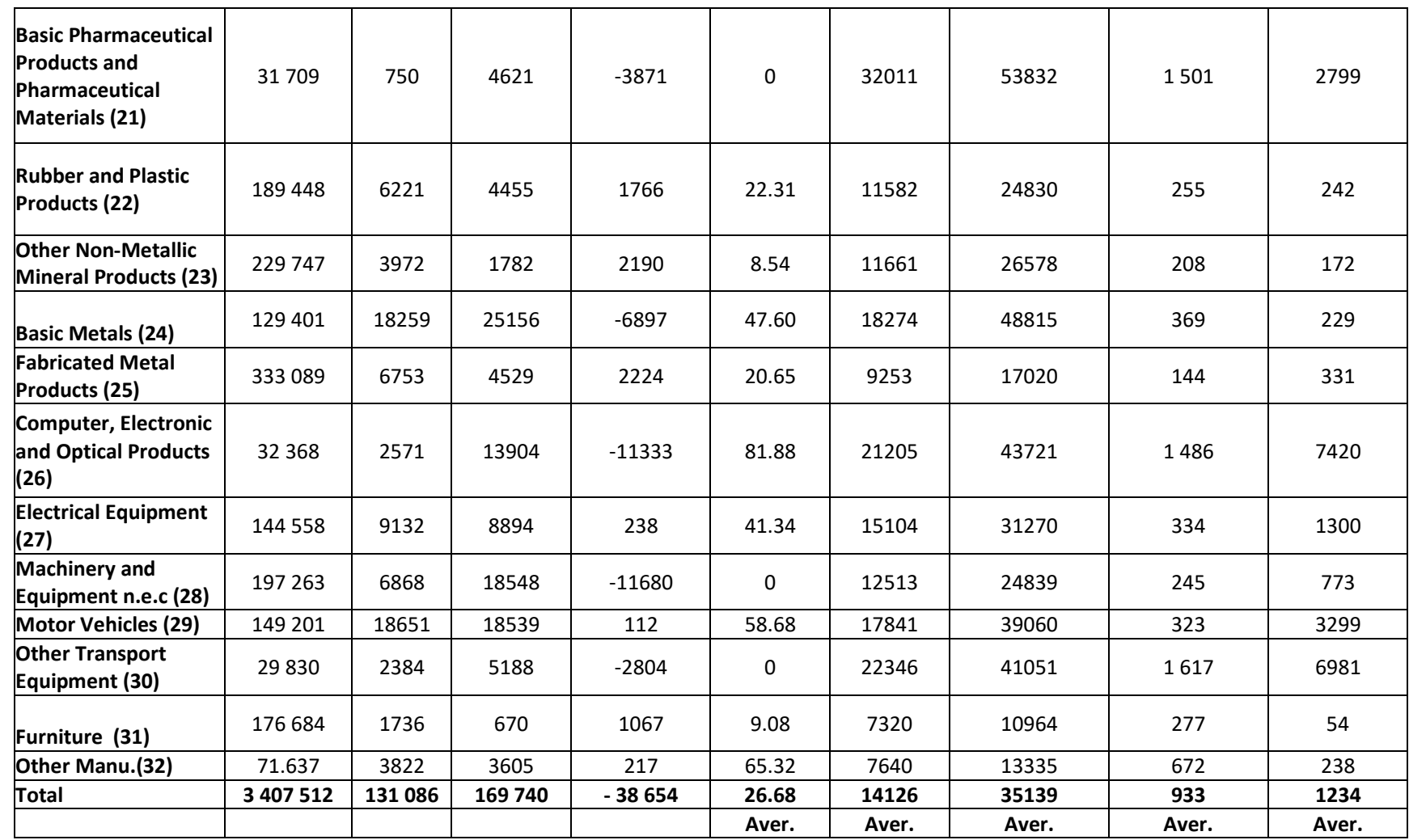

\section{Appendix 2: Import Shares By Industries (2009-2017)}

\begin{tabular}{|c|c|c|}
\hline High Import Share & Medium Import Share & Low Import Share \\
\hline Leather (15) & Beverages (11) & Wearing Apparel (14) \\
\hline Paper and Paper Products (17) & Textiles (13) & $\begin{array}{c}\text { Printing and Reproduction of Recorded } \\
\text { Media (18) }\end{array}$ \\
\hline $\begin{array}{c}\text { Coke and Refined Petroleum Products (19) } \\
\text { Chemicals and Pharmaceutical Products } \\
\text { (20+21) }\end{array}$ & Rood and Wood Products and Cork (16) & Other Non-Metallic Mineral Products (23) \\
\hline Basic Metals (24) & Fabricated Metal Products (25) (31) \\
\hline Computer, Electronic and Optical Products \\
\hline (26)
\end{tabular}

Notes: Import share is defined as imports / (domestic output + imports). High import share industries are defined to be those in which imports comprised at least 20 percent of total new supply for 2009-2017 period. Medium import share industries have import shares of 10 to 20 percent. Low import share industries have import shares of less than 10 percent. Most of the sectors of the Turkish manufacturing industry (12 out of 22) are included in the high import share category. 